\title{
Chemistry
}

\section{Chemical characterization, toxicity, antioxidant and antimicrobial activity of the essential oils of Hymenaea courbaril L. and Syzygium cumini (L.) Skeels}

\author{
Gustavo Oliveira Everton' ${ }^{(D)}$, Ana Patrícia Matos Pereira'iD, \\ Paulo Victor Serra Rosa'iD, Nilton Silva Costa Mafra'iD, \\ Paulo Sérgio Santos Júnior' ${ }^{(D)}$, Franscristhiany Silva Souza'iD, \\ Caritas de Jesus Silva Mendonça' ${ }^{\prime}$, Fernando Carvalho Silva'iD, \\ Paulo Roberto Barros Gomes" (iD, Victor Elias Mouchrek Filho' (D) \\ I,Universidade Federal do Maranhão, São Luís, MA, Brasil \\ "Instituto Federal do Pará, Belém, PA, Brasil
}

\begin{abstract}
This study evaluated the antimicrobial, antioxidant and toxicity activity of essential oils (EOs) of Hymenaea courbaril L. var. courbaril bark and Syzygium cumini (L.) Skeels leaves. The EOs were extracted by hydrodistillation and chemically characterized by gas chromatography coupled to mass spectrometry (GC/MS). The ABTS and DPPH assay were used to evaluate antioxidant activity. For the toxicity assay, lethality was evaluated against Artemia salina Leach. For the antimicrobial assay, the method of Disc Diffusion and Dilution in Broth was applied to obtain the minimum inhibitory concentration and minimum bactericidal. The major constituent of the EO of $\mathrm{H}$. courbaril was $\beta$-ocimene $(23.33 \%)$ and the EO of S. cumini was isocaryophyllene (18.01\%). Both OE showed relevant antioxidant activity and low toxicity against Artemia salina. The EOs showed bactericidal activity against E. coli, S. aureus, P. aeruginosa, Salmonella sp., B. cereus and P. mirabilis. The results obtained are encouraged by the potential use of the OE's studied in the control and fight of pathogenic microorganisms.
\end{abstract}

Keywords: Essential oil; Antimicrobial; Toxicity; Hymenaea courbaril; Syzygium cumini

\section{RESUMO}

Este estudo avaliou a atividade antimicrobiana, antioxidante e toxicidade de óleos essenciais (OE's) das cascas de Hymenaea courbaril L. var. courbaril e folhas de Syzygium cumini (L.) Skeels. Os OE's foram extraídos por hidrodestilação e caracterizados quimicamente por cromatografia gasosa acoplada à espectrometria de massa (CG/EM). O ensaio ABTS e DPPH foram utilizados para avaliar a atividade antioxidante. Para o ensaio de toxicidade, a letalidade foi avaliada frente a Artemia salina Leach. Para o 
ensaio antimicrobiano, o método de Difusão de Disco e Diluição no Caldo foram aplicados para obter a concentração inibidora mínima e bactericida mínima. O principal constituinte do OE de H. courbaril foi $\beta$-ocimeno (23,33\%) e o OE de S. cumini foi isocariofileno (18,01\%). Ambos os OE apresentaram atividade antioxidante relevante e baixa toxicidade frente a Artemia salina. Os OE's apresentaram atividade bactericida contra E. coli, S. aureus, P. aeruginosa, Salmonella sp., B. cereus e P. mirabilis. Os resultados obtidos são encorajados pelo potencial uso dos OE's estudados no controle e combate de microrganismos patogênicos.

Palavras-chave: Óleo essencial; Antimicrobiano; Toxicidade; Hymenaea courbaril; Syzygium cumini

\section{INTRODUCTION}

The use of plants for therapeutic purposes is an ancient practice carried out by human civilization over centuries, based on random discoveries, where products of mineral, vegetable and animal origin were used, these being the main sources of drugs (VARGAS et al., 2019). The properties of medicinal plants are directly related to their essential oils (EOs), which according to are components that integrate the secondary metabolites of plants, that is, they are part of the nonprimal system of these organisms, having functions of protection against elements external to plants (SIMÕES, 2010).

Hymenaea courbaril and Syzygium cumini stand out among medicinal plants with efficient biological potentials. The H. courbaril of the Fabaceae family, which has as popular name jatobá, jatobazeiro or jatobá-verdadeiro. A native, semideciduous species, belonging to the Atlantic Forest biome and occasionally also to the Cerrado, with wide distribution in Brazil, mainly in Piauí and northern Paraná (DUARTE et al., 2016).

In traditional medicine, the use of infusions and decoctions of the stem bark of Hymenaea courbaril is widely indicated, however reports of use of leaves, roots and fruits are also cited (BEZERRA et al., 2013). Tea obtained from the stems of $H$. courbaril is popularly used as analgesic, antiseptic, expectorant, laxative, purgative, sedative, stimulant and tonic, to treat ulcers, inflammations, arthritis and rheumatism (FERNANDES et al., 2015). In addition to studies in relation to the EO 
of the leaves of the $H$. courbaril tree that present antimicrobial potential and antioxidant activity of phenolic compounds present in this plant. Therefore, an important aspect associated with $\mathrm{H}$. courbaril is the presence of these products in its constitution (VEGGI et al., 2014). In this sense, H. courbaril, is a kind of popular use, which presents in its constitution biologically active compounds, and few scientific studies. Fruit peels are often discarded due to this was the object of this study.

S. cumini which is a plant of the Family Myrtaceae, originating in Eastern India, and its leaves are rich in tannins and saponins (PEREIRA et al., 2016), having proven physiological effect in several species, including man (GOULART et al., 2016). Despite this abundance, these fruits are not traditionally consumed. Several studies have demonstrated the pharmacological and biological activities of $S$. cumini such as antidiabetic (SALES et al., 2019; TONG et al., 2014), anti-inflammatory (RIBEIRO et. al., 2014) and antimicrobial (XAVIER, 2015; AYYANAR; SUBASH-BABU, 2012). This natural compound has aroused interest due to its nutritional and therapeutic effects, mainly due to its antioxidant action. The use of seed powder stands out for its hypoglycemic, antibacterial, antifungal and anti-diarrhoeal actions (XAVIER, 2015).

The emerging spread of antimicrobial-resistant bacterial strains is a serious global public health problem and despite the great advance in the development of new broad-spectrum antimicrobials, the indiscriminate use of these drugs has selected resistant microbial populations, thus limiting the therapeutic options of infectious processes (FERREIRA et al., 2010).

In the context of microbial resistance, gram-positive Staphylococcus aureus and Gram-negative Escherichia coli bacteria stand out. S. aureus stands out for being one of the most important pathogens, as it acts as an infectious agent causing a 
series of infections, ranging from localized infections such as abscesses, to disseminated infections such as severe septicemia (ALVES et al., 2016) and E. coli is the most important causative agent of urinary tract infections, which over the years has shown acquired resistance to the main drugs used in empirical therapy of this type of infection, such as fluoroquinolones (MATTOS et al., 2014).

In the studies that aimed to evaluate the epidemiological profile of cases of outbreaks of diseases transmitted by ingestion of contaminated food, they observed that the most significant responsible agents in the positive samples were Gram-negative bacteria, mainly E. coli and Salmonella sp. (ALMEIDA et al., 2013). Salmonella sp. was the pathogen that was most related to outbreaks of diseases transmitted by contaminated food, basing on the realization of its wide distribution in nature, and may be present in water, animals and humans (MARQUES et al., 2013).

S. aureus is an important pathogen associated with nosocomial diseases acquired in the community. Although they may be present in various places of the body, the nasopharynx and oropharynx are the most frequent sites (KLEIN et al., 2013). S. aureus has the ability to asymptomatically colonize normal people. It is estimated that about 20 to $40 \%$ of the world population are asymptomatic nasal carriers of S. aureus and E. coli and with this are at higher risk of infection (NIMMO et al., 2013). Currently, it is almost impossible to speak of hospital infection and not to report $P$. aeruginosa. For, in the last four decades, this microorganism has accounted for $10 \%$ of all cases of nosocomial infections reported (NTZIMANI et al., 2010). Thus, epidemiological studies help in the monitoring of microorganisms of great pathogenic potential.

Approximately $25 \%$ of the drugs prescribed worldwide for the treatment of these infections are derived from plants and of the 252 drugs considered basic and essential by the World Health Organization (WHO) $11 \%$ are exclusively originated 
from plants and a significant number are synthetic drugs obtained from natural precursors (SIMÕES et al., 2016). In Brazil, with the purpose of improving the health service provided to the population, the Unified Health System (UHS) together with the World Health Organization (WHO), recognizes the use of medicinal plants for therapeutic purposes, and ensures the use of these herbal medicines in primary health care (BRASIL, 2011).

In view of the above, the present study evaluated the chemical profile, antioxidant and antimicrobial action potential of The EO of the barks of $\mathrm{H}$. courbaril (jatobá) and Leaves Syzygium cumini (jambolão), applying chemical and physicochemical methodologies, in order to establish the appropriate conditions of stability and aiming to find alternatives in controlof the dissemination of antimicrobial resistance and development of new drugs effective in combating them.

\section{MATERIAL AND METHODS}

\subsection{Plant material}

The collection of plant material used in this research was carried out in October to December 2019. The collection period was based on previous studies that proved better action of the OEs of S. cumini and $\mathrm{H}$. courbaril when collected in the months between October and December compared to those collected between January and September. They were identified by the Herbário Ático Seabra of the Federal University of Maranhão and a sample of each plant was deposited. Leaves of Syzygium cumini (L.) Skeels (record no. 1069) were collected in São Luís (MA) and fruit peels of Hymenaea courbaril L. var. courbaril (record no. 1079) in Palmeirândia (MA). After collection, the plant species were transported to the Laboratory of Research and Application of Essential Oils (LOEPAV-UFMA), where they were submitted to the convective air-drying oven at $45^{\circ} \mathrm{C}$ for 24 hours, and subsequently crushed in a knife mill. 


\subsection{Obtaining the EO}

The plant materials were collected and transported to the Laboratory of Research and Application of Essential Oils (LOEPAV-UFMA), where they were crushed and stored for extraction of the EO. For the extraction of the EO, the hydrodistillation technique was used with a glass Clevenger extractor coupled to a round bottom balloon packed in an electric blanket as a heat generating source. $120 \mathrm{~g}$ of $H$. courbaril and $200 \mathrm{~g}$ of S. cumini was used, adding distilled water (1:10). Hydrodistillation was conducted at $100^{\circ} \mathrm{C}$ for $3 \mathrm{~h}$ and the extracted EO was collected. Each EO was dried by percolation with anhydrous sodium sulfate $\left(\mathrm{Na}_{2} \mathrm{SO}_{4}\right)$ and centrifuged. These operations were performed in triplicates and the samples stored in amber glass ampoules under $4^{\circ} \mathrm{C}$ refrigeration obtained an average yield of $0.46 \%$. Subsequently submitted the analyses.

\subsection{Analyses of chemical constituents}

The constituents of the EOs were identified by gas chromatography coupled to mass spectrometry (CG-MS) in the Fuel, Catalysis and Environmental Center (NCCA) of the Federal University of Maranhão (UFMA).

$1.0 \mathrm{mg}$ of the sample was dissolved in $1000 \mu \mathrm{L}$ of dichloromethane (purity 99.9\%). The conditions of analysis validated were as follows: Method: Adams. M, m; Injected volume: $0.3 \mu \mathrm{L}$; Column : Capillary HP-5MS (5\% diphenyl, 95\% dimethyl polysiloxane ) (Equivalent DB-5MS or CP-Sil 8CB LB/MS), in dimensions (30 m $\times 0.25$ $\mathrm{mm} \times 0.25 \mu \mathrm{m})$; Drag gas : He (99.9995); $1.0 \mathrm{~mL} \cdot \mathrm{min}^{-1}$; Gun: 280 oC, Split mode (1:10); Oven: 40 oC (5.0 min.) up to 240 oC at a rate of 4 oC min-1, from 240 oC to 300 oC (7.5 min) at a rate of 8 oC. $\left.\mathrm{min}^{-1}\right)$; tT $=60.0 \mathrm{~min}$; Detector : EM; El (70 eV); Scan mode (0.5 sec scan-1); Mass range: 40 - 500 daltons (one); Line transfer: 280 oC.; Filament: off 0.0 to $4.0 \mathrm{~min}$; Linear quadrupole mass spectrometer. The AMDIS (Automated Mass spectral Deconvolution Mass \& Identification System) program was used to identify the compounds in the sample. 


\subsection{Total phenolics}

The determination of the total phenolic compounds of the EO was performed with adaptation of the Folin-Ciocalteu method (WATERHOUSE, 2002). We used $5 \mathrm{mg}$ of EO diluted in $1 \mathrm{~mL}$ of ethanol. To this solution was added $3 \mathrm{~mL}$ of distilled water, $500 \mu \mathrm{L}$ of Folin-Ciocalteu reagent and $2.0 \mathrm{~mL}$ of sodium carbonate at $20 \%$. The solution formed was taken to the water bath at $50^{\circ} \mathrm{C}$ for $5 \mathrm{~min}$, removed and left to cool; and then, the reading was performed in a manual spectrophotometer, in a length of $760 \mathrm{~nm}$. The standard curve was expressed in $\mathrm{mg} \mathrm{L}^{-1}$ of tannic acid.

\subsection{Antioxidant activity by the ABTS method}

The determination of antioxidant activity was performed by the ABTS method [2,2-azinobis-(3- ethylbenzotiazolin-6-sulfonic], according to the methodology suggested by Re et al. (1999). The ABTS + radical was prepared by the $5.0 \mathrm{~mL}$ reaction of a $3840 \mu \mathrm{g} \mathrm{mL}-1$ solution of ABTS with $88 \mu \mathrm{L}$ of the $37,840 \mu \mathrm{g} \mathrm{mL}^{-1}$ potassium persulfate solution, the mixture was left in a dark environment for 16 hours. After radical formation, the mixture was diluted in ethanol until absorption from $0.7 \pm 0.01$ to $734 \mathrm{~nm}$.

From the concentrations of the EOs ( 5 to $150 \mu \mathrm{g} \mathrm{mL}^{-1}$ ) the reaction mixture with the radical cation ABTS was prepared. In a dark environment, an aliquot of 30 $\mu \mathrm{L}$ of each EO concentration was transferred in test tubes containing $3.0 \mathrm{~mL}$ of the radical cation ABTS and homogenized in a tube agitator and after 6 minutes the absorption of the reaction mixture was performed in a spectrophotometer of 734 $\mathrm{nm}$.

The capture of the free radical was expressed as a percentage of inhibition (\%l) of the radical action ABTS according to Equation 1 (BABILI et al., 2011), where $A_{A b S_{A B T S}}$ represents the absorption of the radical solution ABTS and ABSAM represents the absorption of the sample. 
From the data obtained, the efficient concentrations $I C_{50}$ and $I C_{90}$ were calculated, defined as the concentration of the sample necessary to kidnap 50\% and $90 \%$ of the ABTS radicals. EO is considered active when it has $\mathrm{IC}_{50}<500 \mu \mathrm{g} \mathrm{mL}$ ${ }^{1}$ (CAMPOS et al., 2003).

\subsection{Antioxidant activity by the DPPH method}

To determine the antioxidant capacity by the DPPH method of the EO, the adapted methodology of Brand-Williams et al. (1995) was used. The radical was prepared by dissolving $3.94 \mathrm{mg}$ of DPPH (2,2-Diphenyl-1-picrylhydrazyl) in $100 \mathrm{~mL}$ of ethanol. From the concentrations of the EOs ( 5 to $150 \mu \mathrm{g} \mathrm{mL}^{-1}$ ) the reaction mixture with the radical cation ABTS was prepared. $50 \mu \mathrm{L}$ of EO was mixed with 950 $\mu \mathrm{L}$ of ethanol, $2 \mathrm{~mL}$ of DPPH radical solution, and completed up to $4 \mathrm{~mL}$ with ethanol, and again homogenized. The mixture was left to react in the dark for 30 minutes and the absorption of the reaction mixture was performed in a spectrophotometer of $517 \mathrm{~nm}$.

The capture of the free radical was expressed as a percentage of inhibition (\%l) of the action of the DPPH radical according to Equation 2 adapted by Babili et al. (2011), where AbS DPPH represents the absorption of the radical solution DPPH and $A B S_{D P P H}$ represents the absorption of the sample.

$\%$ InhibitionDPPH= $\left(\mathrm{ABS}_{\mathrm{DPPH}}-\mathrm{ABS}_{\mathrm{AM}}\right) / \mathrm{ABS}_{\mathrm{DPPH}}$

From the data obtained, the efficient concentrations $I C_{50}$ and $I C_{90}$ were calculated, defined as the concentration of the sample necessary to kidnap 50\% and $90 \%$ of the DPPH radicals. EO is considered active when it has $\mathrm{IC}_{50}<500 \mu \mathrm{g} \mathrm{mL}$ 1 (CAMPOS et al., 2003).

\subsection{Toxicity}

This test was performed according to the methodology described by Meyer et al. (1982). In a rectangular container, with a partition containing holes of approximately $0.02 \mathrm{~cm}$ thickness spaced by $0.5 \mathrm{~cm}$ and evenly distributed, artificial saline solutions ( $60 \mathrm{~g}$ of sea salt/1 $\mathrm{L}$ of distilled water) were added. The container was placed inside an incubator illuminated by a fluorescent lamp, with aeration. 
On one side of this container, about $64 \mathrm{mg}$ of Artemia salina cysts were added, given that they did not cross the partition. The part of the system containing Artemia salina cysts was covered with aluminum foil, so that the organisms, at birth, were attracted by light on the other side of the system, forcing them to cross the partition. This procedure aims to homogenize the physical conditions of the test organisms. Incubation was performed for a period of $48 \mathrm{~h}$. Throughout the test the temperature was monitored.

For the evaluation of the lethality of Artemia salina Leach, a stock saline solution of each EO was prepared at the concentration of $10,000 \mathrm{mg} \mathrm{L}^{-1}$ and 0.02 $\mathrm{mg}$ of Tween 80 (active tense). Aliquots of 5,50 and $500 \mu \mathrm{L}$ of this were transferred to test tubes and completed with saline solution previously prepared up to $5 \mathrm{~mL}$, obtaining concentrations of 10,100 and $1000 \mathrm{mg} \mathrm{L}^{-1}$, respectively. All tests were performed in triplicates, where ten larvae in the nauplium phase were transferred to each of the test tubes.

For white control, $5 \mathrm{~mL}$ of saline solution was used for positive control $\mathrm{K}_{2} \mathrm{Cr}_{2} \mathrm{O}_{7}$ and for negative control $5 \mathrm{~mL}$ of a solution $4 \mathrm{mg} \mathrm{L}^{-1}$ of Tween 80 . After 24 hours of exposure, the live larvae were counted, considering those that did not move during observation or with the slight agitation of the bottle.

To quantify the efficiency of the EO, the Reed \& Muench statistical test (1938) was applied, calculated by Pizzi (1950). The criterion established by Dolabela (1997) was adopted for classification of EO toxicity, being considered highly toxic when $\mathrm{LC}_{50} \leq 80 \mathrm{mg} \mathrm{L}^{-1}$, moderately toxic to $80 \mathrm{mg} \mathrm{L}^{-1} \leq \mathrm{LC}_{50} \geq 250 \mathrm{mg} \mathrm{L}^{-1}$ and mildly toxic or nontoxic when $\mathrm{LC}_{50} \geq 250 \mathrm{mg} \mathrm{L}^{-1}$.

\subsection{Standardization of microbial inoculum for sensitivity tests}

Bacteria strains were used: Escherichia coli (ATCC 25922) and Staphylococcus aureus (ATCC 25923), Pseudomonas aeruginosa (ATCC 15442, Bacillus cereus (ATCC 11778), Proteus mirabilis (ATCC 25933) and Salmonella sp. (ATCC 700623). These were previously identified and confirmed by biochemical tests. 
Pure microbial cultures maintained in TSA Agar were peaked for brain and heart infusion broth (BHI) and incubated at $35{ }^{\circ} \mathrm{C}$ until they reached exponential growth phase (4-6 h). After this period, the cultures had their cell density adjusted in $0.85 \%$ sterile saline solution, in order to obtain turbidity comparable to that of the standard McFarland solution 0.5 , which results in a microbial suspension containing approximately $1.5 \times 108 \mathrm{CFU} \mathrm{\textrm {mL } ^ { - 1 }}$ according to the standards of the Clinical and Laboratory Standards Institute (2020).

\subsection{Disk Diffusion Method}

Antimicrobial activity was performed according to the disc diffusion technique of the Clinical and Laboratory Standards Institute (2020), which standardizes the sensitivity tests of antimicrobials by disc-diffusion, using standardized suspensions of the strains distributed in plates containing Mueller Hinton Agar culture medium (AMH) plus discs containing $20 \mu \mathrm{L}$ of EO. Gentamicin (30 $\mathrm{\mu g}$ ) was used as a positive control. The plates were incubated in a bacteriological greenhouse at $35{ }^{\circ} \mathrm{C} / 24 \mathrm{~h}$. The diameters of the inhibition halos were measured, including the diameter of the disc. These trials were done in triplicate.

\subsection{Inhibitory Concentration and Minimal Bactericidal}

To determine the Minimum Inhibitory Concentration (MIC), the broth dilution technique was used. With serial dilutions of EO in Mueller Hinton Broth (MH), resulting in concentrations of $1000,500,250,100,50,25,10$ and $5 \mu \mathrm{gL}^{-1}$, performing sterility controls and incubation at $35^{\circ} \mathrm{C}$ for 24 hours. After the incubation period, the minimum inhibitory concentration of EO was verified, being defined as the lowest concentration that visibly inhibited bacterial growth (absence of visible cloudiness). Tests performed in triplicate. The Minimum Bactericidal 
Concentration (MBC) was measured from the inoculation of $10 \mu \mathrm{L}$ of the tubes resulting from the dilution in Mueller Hinton Broth, performed a plate count after $24 \mathrm{~h}$, where the plates that did not grow colonies were classified as bactericidal concentrations for the action of EO or EH.

\section{RESULTS AND DISCUSSION}

\subsection{Chemical constituents}

GC/MS allowed the chemical characterization of the EOs and a Figure 1 shows the EO chromatogram of $H$. courbaril where 27 peaks are displayed.

Figure $6-H$. courbaril EO chromatogram

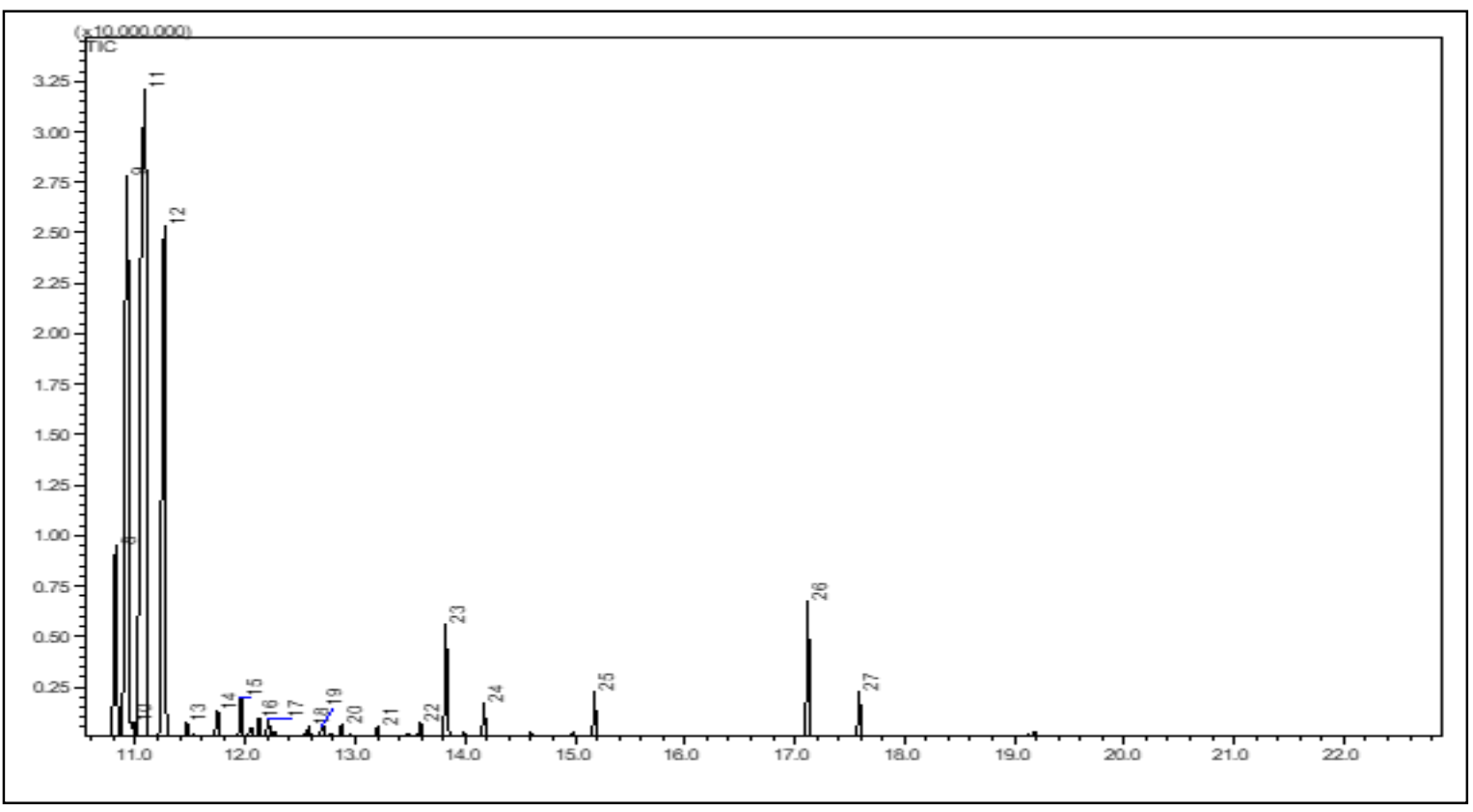

Table 1 shows the chemical constituents obtained in the EO $\mathrm{H}$. courbaril sample. 25 constituents were identified and the majority were: $\beta$-ocimene (23.33\%), d-limonene (13.51\%), a-pinene (12.33\%), $\beta$-pinene (11.79\%) and $\beta$-myrcene $(11,38 \%)$. 
Table 1 - Chemical constituents identified in the EO of $\mathrm{H}$. courbaril

\begin{tabular}{|c|c|c|c|c|}
\hline Pico & RT & Constituintes NIST08 & Classe & $\%$ \\
\hline 1 & 6,697 & (E)-2-hexenal & Monoterpene & 0,90 \\
\hline 2 & 6,760 & (Z)-hex-3-en-1-ol & Monoterpene & 0,44 \\
\hline 3 & 8,823 & a-pinene & Monoterpene & 12,33 \\
\hline 4 & 9,196 & Canfene & Monoterpene & 4,31 \\
\hline 5 & 9,843 & $\beta$-pinene & Monoterpene & 11,79 \\
\hline 6 & 10,118 & $\beta$-myrcene & Monoterpene & 11,38 \\
\hline 7 & 10,427 & (E) 3-hexen-1-ol & Monoterpene & 0,08 \\
\hline 8 & 10,816 & Ocimene & Monoterpene & 3,36 \\
\hline 9 & 10,925 & d-limonene & Monoterpene & 13,51 \\
\hline 10 & 10,976 & Eucalyptol & Monoterpene & 0,20 \\
\hline 11 & 11,085 & $\beta$-ocimene & Monoterpene & 23,33 \\
\hline 12 & 11,261 & $\beta$-cis-ocimene & Monoterpene & 10,59 \\
\hline 13 & 11,466 & $y$-terpinene & Monoterpene & 0,20 \\
\hline 14 & 11,745 & a-pinene epoxide & Monoterpene & 0,36 \\
\hline 15 & 11,958 & $\delta$-carene & Monoterpene & 0,56 \\
\hline 16 & 12,122 & a-pinene oxide & Monoterpene & 0,26 \\
\hline 17 & 12,207 & Linalool & Monoterpene & 0,25 \\
\hline 18 & 12,576 & 2-fencanol & Monoterpene & 0,14 \\
\hline 19 & 12,706 & 1-noneno-3-ino & Monoterpene & 0,20 \\
\hline 20 & 12,875 & Oxirano & Monoterpene & 0,17 \\
\hline 21 & 13,201 & Canfenilanol & Monoterpene & 0,15 \\
\hline 22 & 13,596 & p-ment-1-en-4-ol & Monoterpene & 0,16 \\
\hline 23 & 13,826 & a-terpineol & Monoterpene & 1,56 \\
\hline 24 & 14,173 & acetato de fenila & Monoterpene & 0,48 \\
\hline 25 & 15,179 & borneol & Monoterpene & 0,63 \\
\hline $26 / 27$ & - & Unidentified & - & 1,46 \\
\hline
\end{tabular}

Discordant results were observed by Aguiar et al. (2010) verified the chromatographic analyses performed in GC/MS of the EO of the ripe and green fruit peels of $H$. courbaril, it was possible to detect 47 compounds, representing $86.1 \%$ of the constituents of the EO. The major components of The EO of ripe fruit 
peels were: a-copaene (11.1\%), sphatulenol (10.1\%), $\beta$-selinene $(8.2 \%), \quad y$ muurolene (7.9\%) and buckylene oxide (6.9\%). However, the EO obtained from the peels of the green fruits of $H$. courbaril presented the major components: germacrene-D (31.9\%), $\beta$-caryophyllene (27.1\%), bicyclogermacreno (6.5\%), ahumulene (4.2\%) and a-copaene (4.2\%).

Mercês et al. (2018) evaluated the chemical composition of the EO of $H$. courbaril by CG/MS, 26 compounds were identified, representing $76.03 \%$ of the constituents of the EO. The analysis revealed the hydrophyllene oxide and $\beta$ caryophyllene as the majority compounds of this EO with $20.63 \%$ and $16.78 \%$, respectively. Costa et al. (2017) evaluated the composition of EO of ripe fruit peels and leaves of $H$. courbaril, identified the following major components: a-copaene, spathulenol and $\beta$-selinene $(11.1 \%, 10.1 \%$ and $8.2 \%$, respectively), which were present in leaves in small concentrations in EO of leaves of $H$. courbaril.

According to Lima et al. (2005) a-pinene and $\beta$-pinene monoterpenes demonstrate satisfactory antifungal activity of the components, as well as Gundidza et al. (2008) that prove the antimicrobial action of this EO on Escherichia coli, Clostridium perfringens and Aspergillus flavus, the antimicrobial activity found is associated with the high concentration of the monoterpene. Guerra et al. (2014) reported that $\beta$-ocimene is one of the major components of EO of Schinus terebenthifolius leaves. This monoterpene has antimicrobial activity against Staphylococcus aureus strains. Demonstrating a strong promise in the fight against pathogenic microorganisms. Figure 2 shows the EO chromatogram of S. cumini where 28 peaks are displayed. 
Figure 2 - Cromatograma do EO de S. cumini

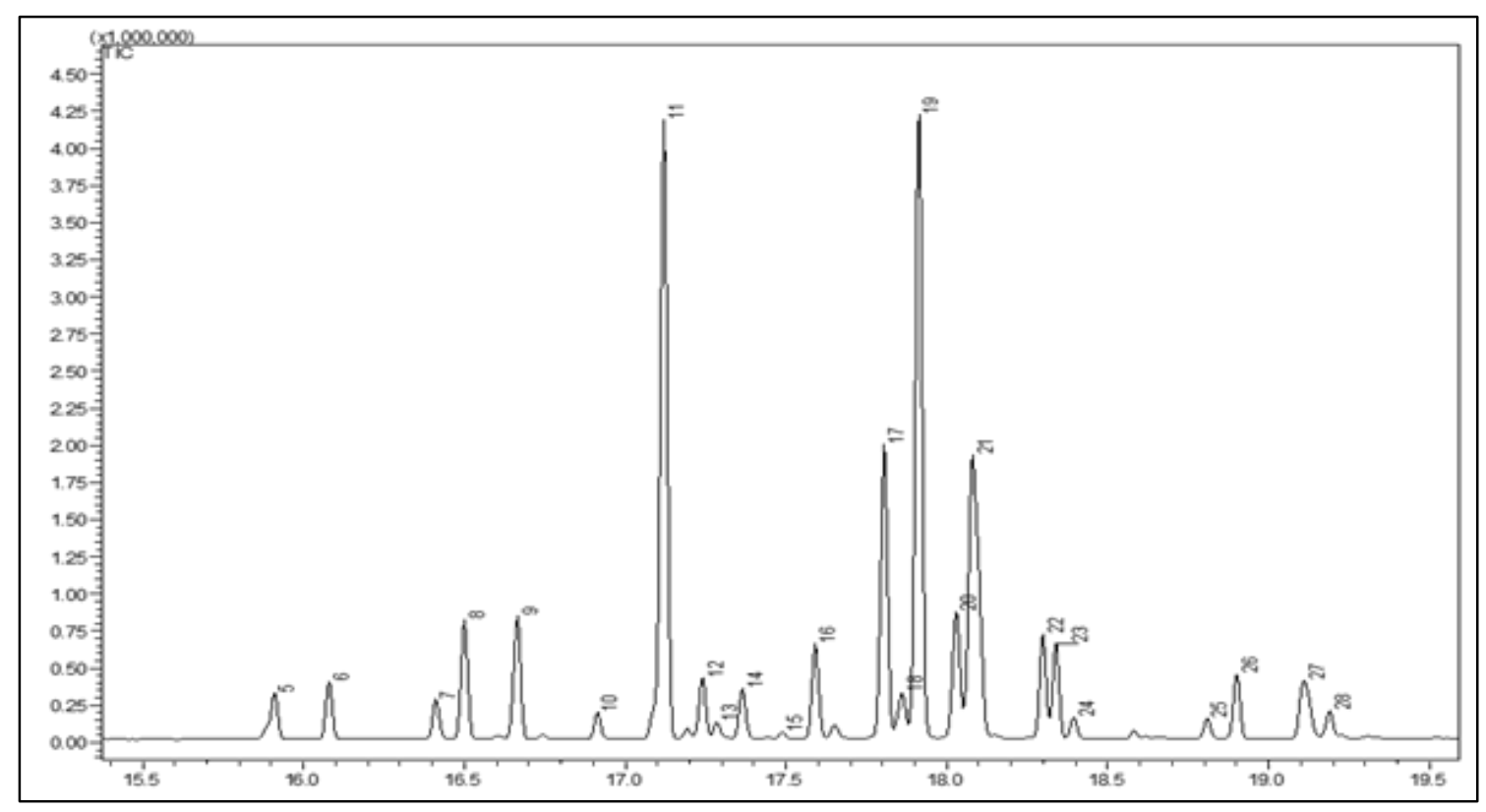

Table 2 shows the chemical constituents obtained from the EO S. cumini sample. 28 constituents were identified and the majority were: isocaryophyllene (18.01\%), naphthalene (17.37\%) and longifolene (11.65\%).

Table 2 - Chemical constituents identified in the EO of S. cumini

\begin{tabular}{lcccc}
\hline Order & RT (min) & Constituents NIST08 & Class & \% T \\
\hline 1 & 7,523 & 1-(1-metil-2-ciclopenten-1-il) - & Monoterpene & 0,28 \\
2 & etanone & Monoterpene & 9,61 \\
3 & 8,798 & dimer $\beta$-pinene & Monoterpene & 0,33 \\
4 & 9,817 & a-sabinene & Monoterpene & 0,29 \\
5 & 10,896 & d-Limonene & Monoterpene & 1,50 \\
6 & 15,910 & p-ment-3-ene & Sesquisterpene & 1,50 \\
7 & 16,079 & a-cubebene & Sesquisterpene & 1,07 \\
8 & 16,411 & a-copaene & Sesquisterpene & 3,21 \\
9 & 16,500 & B-copaene & Sesquisterpene & 3,44 \\
10 & 16,665 & guaia-10 (14), 11-diene & Sesquisterpene & 0,70 \\
11 & 16,913 & 4-aromadendrene & Sesquisterpene & 18,01 \\
12 & 17,120 & Isocaryophyllene & Sesquisterpene & 1,68 \\
\hline
\end{tabular}




\begin{tabular}{lcccc}
\hline Conclusion & \multicolumn{3}{c}{ Class } & \%T \\
\hline Order & RT $(\mathbf{m i n})$ & Constituents NIST08 & Sesquisterpene & 0,49 \\
\hline 13 & 17,285 & a-guaiene & Sesquisterpene & 1,40 \\
14 & 17,365 & Spathulenol & Sesquisterpene & 0,22 \\
15 & 17,489 & isogermacrene $D$ & Sesquisterpene & 2,62 \\
16 & 17,591 & a-humulene & Sesquisterpene & 8,28 \\
17 & 17,805 & Y-cadinene & Monoterpene & 1,44 \\
18 & 17,860 & naphtaleno (isômero) & Monoterpene & 17,37 \\
19 & 17,913 & naphtaleno (isômero) & Sesquisterpene & 3,79 \\
20 & 18,029 & Virdiflorene & Sesquisterpene & 11,65 \\
21 & 18,080 & longifolene (V4) & Sesquisterpene & 2,79 \\
22 & 18,298 & $(+)$ - $\delta$-cadinene & Sesquisterpene & 2,41 \\
23 & 18,339 & $(+)$ - $\delta$-cadinene (isomer) & Sesquisterpene & 0,59 \\
24 & 18,394 & Calamenene & Sesquisterpene & 0,54 \\
25 & 18,810 & Nerolidol & Sesquisterpene & 1,78 \\
26 & 18,901 & Y-elemene & Monoterpene & 2,35 \\
27 & 19,110 & dietil ftalato & Sesquisterpene & 0,66 \\
28 & 19,190 & caryophyllene oxide & &
\end{tabular}

Discordant results were observed by Mohamed et al. (2013) evaluated the chemical composition of EO of S. cumini leaves through GC-MS analysis, identified 49 chemical components representing about $98.3 \%$ of the EOs. The abundant constituents of the oil were: a-pinene $(32.32 \%), \beta$-pinene $(12.44 \%)$, transcaryophyllene $(11.19 \%), 1,3,6$-octatene $(8.41 \%)$, delta-3-carene $(5.55 \%)$, acaryophyllene (4.36\%) and a-limonene (3.42\%).

Machado et al. (2013) identified 12 chemical compounds of EO from S. cumini leaves, by CG-MS method. The major components were: a-caylophyllene (25.24\%), $\beta$-caylophyllene (16.00\%) and a-terpine (9.08\%). Most of the constituents found are sesquiterpenes such as a-cayophyllene and $\beta$-cariophyllene, their alcohol and epoxide, as well as terpineol. Compounds found in this work in smaller compositions.

Dias et al. (2013) evaluated the chemical composition of the EO of jambolão leaves, found 11 chemical compounds present, reaching about $99.98 \%$ of the total constitution, the major components verified in this EO are: $a-p i n e n e ~(31.85 \%),(Z)-$ 


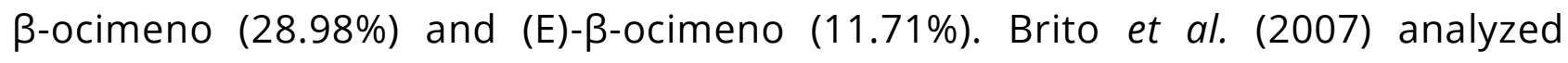
assiduity of the compounds present and characterized that a-pinene and ocimen isomers are main constituents of EOs isolated from leaves, stems and fruits of $S$. cumini.

Nishandhini et al. (2015) analyzed the chemical composition of EO of the pulp of green fruits and leaves of S. cumini, using cg-ms and CG-FID (Gas Chromatography - Flame Ionization Detector) techniques. They identified 34 chemical components representing $99.3 \%$ of green fruit pulp oil and 66 components constituting $95.3 \%$ of leaf EO. The main components of EO of green fruit pulp were: a-pinene (12.4\%), $\beta$-pinene (8.0\%), myrcene $(8.4 \%)$, aterpinessential (7.4\%), $\delta$-cadinene (7.7\%) and a-cadinol (25.8\%). However, the main components of leaf EO were: a-pinene (21.5\%), trans-ocimen (6.8\%), aterpinessential oil (9.5\%) and $\delta$-cadine (8.3\%).

Yang-jiang et al. (2011) analyzed the major components of Rosmarinus officinalis EO, known as rosemary. They identified that the major components were: 1.8-Cineol (26.54\%) and alpha-pinene (20.14\%). Making it possible to conclude that a-pinene bought antimicrobial activity on the strains of S. epidermidis, S. aureus, $B$. subtilis, P. vulgaris, P. aeruginosa, E. coli, C. albicans and A. niger.

Celedonio et al. (2008) reported the peripheral antinociceptive effect and antiedematous activity of a-pinene and Croton argyrophylloides EO, which is the major compound of this EO. Garcia et al. (2008) evaluated the action of a-pinene and citral monoterpenes, in which they obtained as results an excellent fungicide activity when placed in front of the fungi Colletotrichum musae, Colletotrichum gloeosporioides and Fusarium subglutinans f.sp ananás.

\subsection{Total phenolics}

The amount of total phenolics found in the EO of $H$. courbaril L was 490.353 mg EAT g-1. Similar behavior was reported in studies by Vencato et al. (2016) and Veggi et al. (2014) for The EO of $\mathrm{H}$. courbaril bark the values found were respectively 516.89 and $335.0 \mathrm{mg}^{\mathrm{EAT}} \mathrm{g}^{-1}$. According to Table 4, the total phenolic content for

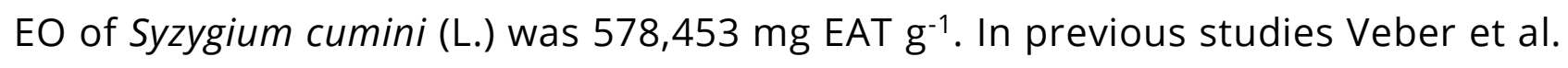
(2015) and Santos (2017) determined the presence of total phenolic compounds in leaves of Syzygium cumini (L.) by different methods, where values ranged from 


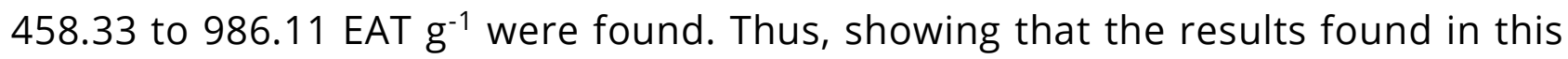
study are in accordance with the literature.

The peels of the fruit of $H$. courbaril $L$ and the leaves Syzygium cumini (L.) presented in this study significant amounts of total phenols. Variable levels of phenolic compounds are naturally produced as secondary metabolites in vegetables. Phenolic quantitative may oscillate according to the physiological need of the plant, being some reasons linked to physiological stress, attack by phytopathogens, insects or herbivore animals (Oliveira et al. 2014).

Phenolic compounds present as one of the chemical groups, flavonoids that present important antioxidant action (SILVA et al., 2010). These compounds include simple molecules and also molecules with high polymerization, present in vegetables in free form or linked to sugars or proteins. More than 8000 different types have already been found in plants and are classified as little or highly distributed in nature. Among those of little distribution are simple phenols, 33 pyrocatechol, hydroquinone, resorcinol, tannins, lignin and also aldehydes derived from benzoic acids that are present in some essential oils. In the group of highly distributed are flavonoids and derivatives and phenolic and coumarin acids (SILVA, 2010).

These compounds act as antioxidants, because in addition to providing electrons or hydrogen, there is also the formation of stable intermediate radicals during the reaction with free radicals. They are characterized as molecules that have a benzene ring linked to one or more hydroxyl groups (SILVA et al., 2010; JARDINI, 2010).

\subsection{Antioxidant activity}

Figure 8 shows the graphs that relate the concentration of EOs in $\mathrm{mg} \mathrm{L}^{-1}$ and the percentage of inhibition of the radical ABTS and DPPH. The equations of the lines obtained using the ABTS test were $y=0.0140 x+0.352\left(R^{2}=0.9802\right)$ for the EO of H. courbaril; $y=0.0153 x+0.3872\left(R^{2}=0.9877\right)$ for The EO of S. cumini. For the DPPH test, the equations of the lines were $y=0.0131 x+0.1067\left(R^{2}=0.9690\right)$; 
$y=0.0096+0.0208(R 2=0.9871)$ for $H$. courbaril and $S$. cumini, respectively. From these equations, the respective values of the effective concentration or $\mathrm{IC}_{50}$ and IC 90 were calculated.

Figure 3 - Percentage inhibition versus concentration of EOs (a) ABTS EO H. courbaril (b) DPPH EO H. courbaril (c) ABTS EO S. cumini (d) DPPH EO S. cumini

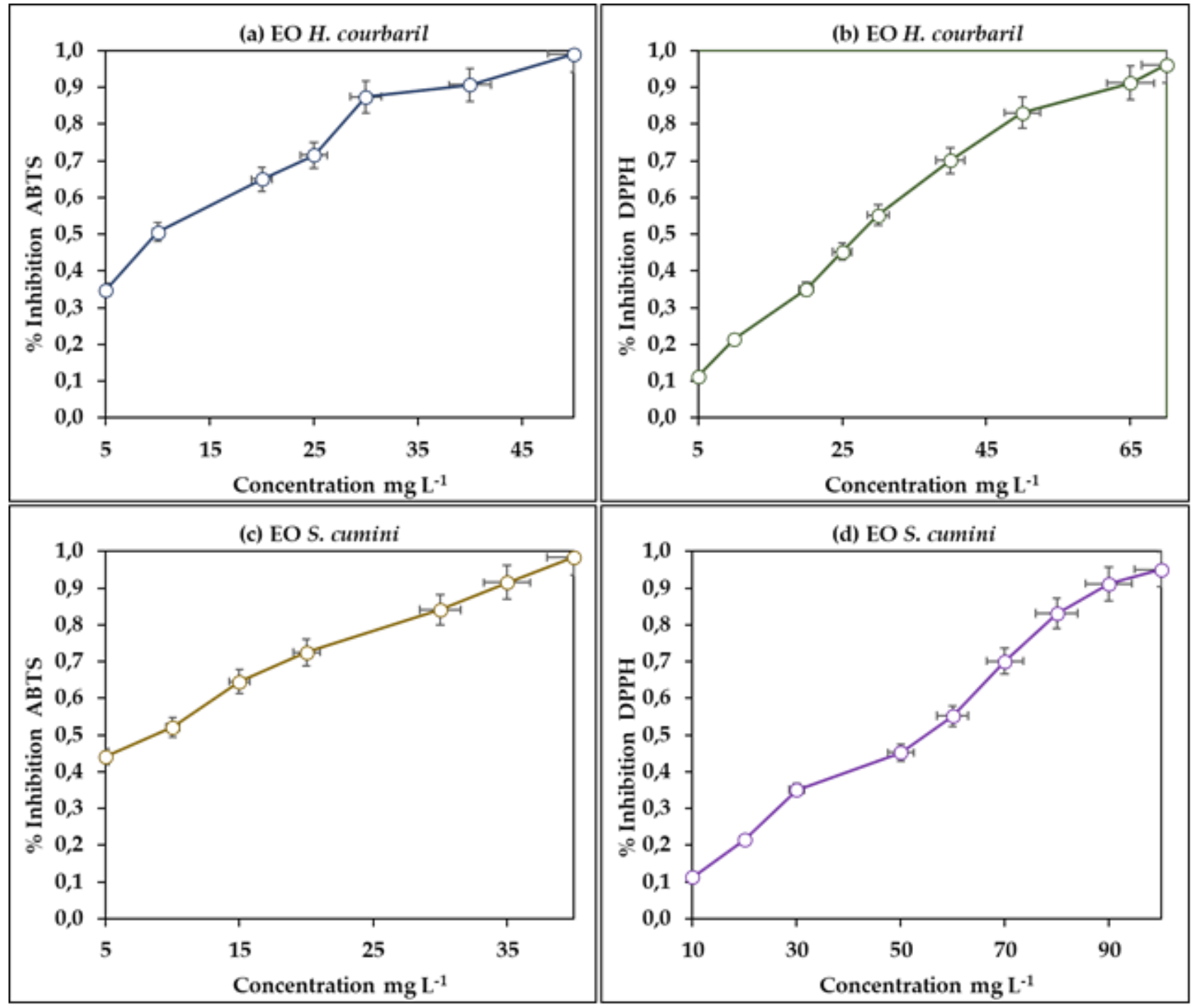

The results of the calculations of antioxidant potentials of The EO of $H$. courbaril and S. cumini, shown in Table 3, were interpreted based on the efficient concentration $\mathrm{IC}_{50}$ and $\mathrm{IC}_{90}$, in $\mathrm{mg} \mathrm{L}^{-1}$. Table 3 presents the results obtained for the antioxidant capacity of the EOs. 
Table 3 - Antioxidant capacity of EOs

\begin{tabular}{lccc}
\hline EO & Method & IC $_{\mathbf{5 0}} \mathbf{~ m g ~ L}^{-1}$ & I $\mathbf{9 0}_{\mathbf{9 0}} \mathbf{~ g ~ L}^{-\mathbf{1}}$ \\
\hline H. courbaril & ABTS & 10,57 & 39,14 \\
S. cumini & & 7,37 & 33,52 \\
H. courbaril & & 30,02 & 60,56 \\
S. cumini & DPPH & 49,92 & 91,58 \\
\hline
\end{tabular}

According to Sousa et al. (2011) and Mishra et al. (2012), the lower the CI50 value, the higher the antioxidant activity of the plant compound, since lower oil concentration is needed to reduce the DPPH and ABTS radical by $50 \%$. Thus, when analyzing Table 5, it was verified that the essential oil of S. cumini showed better antioxidant activity by the ABTS method, in relation to the EO of $\mathrm{H}$. courbaril.

Sousa et al. (2016) also found antioxidant activity according to the ABTS methodology for S. cumini extract, with a value of $43.67 \pm 0.2$ expressed in trolox g$1 \mu \mathrm{mol}$. Almada (2013) also evaluated the antioxidant activity of the species of $S$. cumini, and found $\mathrm{Cl} 50$ of 2,148.88 $\pm 140.26 \mu \mathrm{mol}$ of Trolox.g ${ }^{-1}$. Miranda (2019) when evaluating the biological activity of $H$. courbaril and other plants, showed antioxidant capacity with $\mathrm{IC}_{50}$ of $201.7 \mu \mathrm{g} \mathrm{mL}-1$, being related to its phenol concentration.

According to the results found using the DPPH methodology, $H$. courbaril proved to be more efficient. These data are considerable, since Ucker et al. (2016) did not find antioxidant activity in the DPPH assay of The EO of S. cumini seeds. In a study conducted by Luzia \& Jorge (2009) to evaluate the antioxidant activity of $S$. cumini, they revealed maximum inhibition of the extract with values of $94.98 \%$ and $118.66 \mu \mathrm{g} \mathrm{mL}{ }^{-1}$. Similarly, Figueiredo (2014) demonstrated that the hydroethanolic extract of $H$. courbaril seed presented lower $\mathrm{Cl} 50$ value among the analyzed samples (149.45 $\left.\mathrm{g} \mathrm{mL}^{-1}\right)$. Veggi et al. (2014), when using the extract of $H$. courbaril 
obtained by extraction by supercritical fluid, presented a higher value of $\mathrm{IC}_{50}$ of $200 \mu \mathrm{g} \mathrm{mL}^{-1}$. Therefore, in this study it is possible to observe considerable antioxidant action of the EOs of S. cumini and $H$. courbaril, being subject to studies for use in the different industrial branches.

\subsection{Toxicity}

Table 4 describes the mortality data for three concentrations $(1000,100,10$ mg L-1), and its subsequent classification of the toxicity assay performed of The EOs of H. courbaril L. and S. cumini (L.) against Artemia salina L. The test result showed the relationship of organisms (living and dead) at the end of the assay.

Table 4 - Toxicity of EOs

\begin{tabular}{lcccc}
\hline EO & Concentration $\mathbf{~ m ~ L ~ L ~}^{-\mathbf{1}}$ & \% Mortality & $\mathbf{L C}_{\mathbf{5 0}}$ & Classification \\
\hline H. courbaril & 1000 & 60 & & Nontoxic \\
& 100 & 30 & $354,8 \mathrm{mg} \mathrm{L}^{-1}$ & (potential for encouraged \\
& 10 & 10 & application) \\
S. cumini & 1000 & 60 & Nontoxic \\
& 100 & 25 & $398 \mathrm{mg} \mathrm{L}^{-1}$ & (potential for encouraged \\
& 10 & 10 & & application) \\
\hline
\end{tabular}

The results of the Artemia salina test showed a decreasing trend in the percentage of survival, with the decrease in the concentration of the sample. It was observed that the highest mortality rate was found at the concentration of 1000 $\mathrm{mg} \mathrm{L}^{-1}$ with $60 \%$ in $24 \mathrm{~h}$. The analyzed EOs presented values of $\mathrm{LC}_{50} \geq 250 \mathrm{mg} \mathrm{L}^{-1}$, thus indicating that it was nontoxic according to the reference methodology used for the test (DOLABELLA, 1997). Data on the toxicity of The EO of the bark of $H$. courbaril L against Artemia salina L. were not found in the scientific literature, emphasizing the importance of the findings of the present study. 
The EO of Syzygium cumini (L.) did not present toxicity because it exhibited $\mathrm{LC}_{50}$ of $398 \mathrm{mg} \mathrm{L}^{-1}$, a value higher than the reference to classify it as nontoxic, so this EO has its application potential acceptable and encouraged. In a study developed by Bitencourt et al. (2016), when using the leaves of Syzygium cumini (L.) showed a non-toxic effect against Artemia salina as well as George et al. (2017) who also found similar results, such data corroborate the results of this study.

The toxicity of a plant is considered to be the ability of the product studied to cause some imbalance, serious damage or even lead to death (LIMA et al., 2014). Tests with natural products have revealed relevant biological activities. One trial that can demonstrate such activities is the bioassay using Artemia salina. There are numerous advantages to using mini crustaceans in scientific trials, the main ones include low cost, speed, easy maintenance and the use of a small sample (SAYFRIED[A12], 2017).

In vitro toxicity tests may be useful for the follow-up of action research of substances still unknown, as they provide preliminary data for evaluations in in vivo research, in order to elucidate the study of doses and the establishment of the dose-dependence correlation with the physiological effects manifested. In general, bioactive compounds are toxic to larvae of Artemia salina (BARCELOS et al., 2017; MASSUD-FILHO et al., 2016). Thus, lethality to this microcrustacean can be used as a quick and simple preliminary test during the isolation of natural products(COE et al., 2010).

\subsection{Antimicrobial activity}

The results obtained with the essential oils of $H$. courbaril and S. cumini using the diffusion disc method are shown in Table 5. The antimicrobial activity of The EOs was performed against the bacteria E. coli, S. aureus, P. aeruginosa, Salmonella 
sp., B. cereus and $P$. mirabilis. The same table also presents the minimum inhibitory concentrations (MICs) and minimum bactericides (MBCs), after performing the broth dilution technique.

Table 5 - Sensitivity of microbial strains for action of EOs in the face of the microorganisms tested

EO H. courbaril

\begin{tabular}{lcccccc}
\hline Species & DIH & MIC & MBC & DIH & MIC & MBC \\
E. coli & 21 & 190 & 490 & 17 & 250 & 600 \\
S. aureus & 33 & 170 & 450 & 32 & 150 & 390 \\
P. aeruginosa & 11 & 800 & 1300 & 9 & 500 & 1000 \\
Salmonella sp. & 12 & 500 & 900 & 13 & 350 & 800 \\
B. cereus & 15 & 470 & 530 & 22 & 200 & 780 \\
P. mirabilis & 10 & 430 & 900 & 11 & 400 & 820 \\
\hline
\end{tabular}

Note: $\mathrm{DIH}$ - average diameters of inhibition halos $(\mathrm{mm})$; MIC- minimum inhibitory concentration $\left(\mu \mathrm{g} \mathrm{\textrm {mL } ^ { - }}\right.$ $\left.{ }^{1}\right)$; MBC- minimum bactericidal concentration $\left(\mu \mathrm{g} \mathrm{mL}^{-1}\right)$; $\mathrm{NI}^{*}$ - there was no inhibition of the microorganism by the essential oil tested.

According to the results observed, it is observed that the bacteria presented sensitivity to the EOs tested. A variation in inhibition halos covered between 9 and $33 \mathrm{~mm}$ (EO-sensitive strains) was detected. The EO of $H$. courbaril revealed antimicrobial activity against all tested strains, but exhibited a higher inhibition halo in the S. aureus strain $(33 \mathrm{~mm})$. These results are in accordance with the analyses pointed out by Sales (2014), who when testing the antimicrobial action of H. courbaril $\mathrm{O}$ against 8 microbial strains, pointed out sensitivity only to grampositive bacterial strains of $S$. aureus at concentrations of 50 and $100 \mathrm{mg} \mathrm{mL}^{-1}$ of EO. Mercês et al. (2013), when performing a serial microdilution test, reported oil activity for all bacteria tested, including S. aureus and E. coli.

When analyzing in vitro the antimicrobial activity of three plant species, including H. courbaril on standard strains, Fernandes et al. (2005), observed that 
jatobá hydroalcoholic extract inhibited about $60 \%$ of Gram-positive bacteria and did not present inhibition against Gram-negative bacteria species. According to the authors, $H$. courbaril has chemical compounds that may be associated with the antimicrobial potential of the plant.

However, Pereira (2007) found a higher antimicrobial potential on the gramnegative bacterium P. aeruginosa strain, a result contrary to that of this study. The same was presented by Verpoorte and Dihal (1987), in relation to the bark extract of $H$. courbaril, who obtained halo inhibition $<15 \mathrm{~mm}$ under the concentration of 50 $\mathrm{mg} \mathrm{mL}^{-1}$ with gram-negative strains of Escherichia coli and Pseudomonas aeruginosa.

In the present investigation, The EO of S. cumini was more effective especially against Gram-positive bacteria, such as $S$. aureus $(32 \mathrm{~mm})$ and $B$. cereus (22 mm). These results verify the relevance of this study, since Loguercio et al. (2005), when investigating the antimicrobial action of S. cumini extract, found lower inhibition halos than this study for these same bacteria. In the present investigation, the EO of $S$. cumini was more effective especially against Gram-positive bacteria, such as $S$. aureus $(32 \mathrm{~mm})$ and $B$. cereus $(22 \mathrm{~mm})$. These results verify the relevance of this study, since Loguercio et al. (2005), when investigating the antimicrobial action of S. cumini extract, found lower inhibition halos than this study for these same bacteria.

In this sense, Shafi et al. (2002) stated that the EO of S. cumini was more efficient in its antimicrobial action than S. travancoricum. Ucker et al. (2016), when evaluating the antimicrobial activity of EO of leaves and seeds of S. cumini, using another methodology for classifying antimicrobial action on substances, verified mean inhibition in relation to $S$. aureus and weak for other Gram-negative bacteria.

Most studies related to the investigation of the antibacterial action of EOs explain that they have lower sensitivity to Gram-negative bacteria. Thus, the 
sensitivity rates compared to the isolates in this study can be explained by the fact that Gram-negative bacteria, such as E. coli, contain a cell wall with double protection separated by glycopeptide, which decreases the action of antimicrobials (Hirsh et al. 2003).

The MIC of the EOs followed the classification of Aligiannis et al. (2001), which proposes to classify plant products based on the results of the MIC. Strong inhibitors: MIC up to $500 \mu \mathrm{g} \mathrm{mL}^{-1}$; moderate inhibitors: MIC between 600 and 1000 $\mu \mathrm{g} \mathrm{mL} \mathrm{mL}^{-1}$; weak inhibitors: MIC above $1000 \mu \mathrm{gL}^{-1}$.

The MIC of H. courbaril EO showed strong inhibition against five bacteria and moderate inhibition over $P$. aeruginosa $\left(800 \mu \mathrm{g} \mathrm{mL}^{-1}\right)$. The EO of S. cumini showed strong inhibition on all bacterial strains tested. Thus, according to the results obtained, it is noted that the EO of S. cumini was more effective to inhibit the pathogenic bacteria tested.

However, Michelin et al. (2005) found that the extract of S. cumini did not inhibit standard strains of E. coli (ATCC 25922), P. aeruginosa (ATCC 27583) and S. aureus (ATCC29213), demonstrating the importance of the results exhibited in this study with essential oils.

The results of the broth microdilution test performed by Martins et al. (2010) demonstrated the MIC of the crude extract of $H$. courbaril bark as a strong inhibitor, by presenting inhibition in the concentration of $350 \mathrm{\mu g} \mathrm{mL}^{-1}$ for the clinical isolates S. aureus, E. coli and P. aeruginosa.

The Tests of Minimum Bactericidal Concentrations (MBC) showed better results at concentrations of 450 and $390 \mathrm{\mu g} \mathrm{mL}^{-1}$ compared to S. aureus, for the EOs of $H$. courbaril and S. cumini, respectively, when compared the bactericidal action on P. aeruginosa which were only from $1300 \mu \mathrm{gL}^{-1}$ (H. courbaril) and $1000 \mu \mathrm{gL}^{-}$ 1 (S. cumini). 
The authors Chandrasekaran \& Venkatesalu (2004) tested extracts of S. cumini against Gram-positive bacteria (B. subtilis, S. aureus), Gram-negative (S. typhimurium, P. aeruginosa, K. pneumoniae and E. coli) and fungal strains. Bacterial activity showed that the $E$. coli strain presented a similar value $\left(500 \mu \mathrm{g} \mathrm{mL}^{-1}\right)$ to that of this study and only two bacterial strains (B. subtilis and $S$. aureus) had satisfactory bactericidal action.

In a study conducted by Fernandes et al. (2015), they found that the bactericidal potential of the ethanol extract of $H$. courbaril was better at the concentration of $127.71 \mu \mathrm{g} \mathrm{mL}^{-1}$, compared to E. coli isolates, while in this study, the action occurred at a higher concentration (490 $\left.\mu \mathrm{g} \mathrm{mL}^{-1}\right)$. Garcia et al. (2011) revealed that the bactericidal action of $H$. courbaril was much higher than the other extracts tested on S. aureus, presenting MBC of $3.33 \mathrm{mg} \mathrm{mL}^{-1}$.

Thus, since EOs have efficient activity against bacteria and toxicity against the non-target Artemia salina Leach organisms, it is important to highlight that Artemia salina Leach is a highly resistant microcrustacean and therefore used in models of toxicity studies of natural products, which would justify the non-lethal action of EOs in organisms.

\section{CONCLUSIONS}

GC/MS allowed the chemical characterization of EOs and quantified the $\beta$ ocimene EO as the majority of The EO and The EO of S. cumini isokaryophyllene.Both EOs presented atoxicity against Artemia salina. The antioxidant activity of The EOs was efficient. All strains tested were sensitive to bactericidal action of EOs. The results obtained are encouraged by the potential use of the OE's studied in the control and fight of pathogenic microorganisms. 


\section{ACKNOWLEDGMENT}

The authors thank the Laboratory of Research and Application of Essential Oils (LOEPAV/UFMA), the Catalysis, Fuels and Environmental Center (NCCA/UFMA) and the Federal University of Maranhão.

\section{REFERENCES}

AGUIAR, J. C. D. et al. Chemical constituents and larvicidal activity of Hymenaea courbaril fruit peel. Natural Product Communications, v. 5, n. 12, 2010.

ALIGIANNIS, N. et al. Composition and antimicrobial activity of the essential oil of two Origanum species. Journal of Agricultural and Food Chemistry, v.49, n.4168, 2001.

ALMADA, C. N. Atividade antioxidante do extrato etanólico de folhas de azeitona da terra (Syzygium Cumini L.) e seu efeito contra estresse induzido por paracetamol. Dissertação (Mestrado em Bioquímica) - Centro de Ciências, Universidade Federal do Ceará, Fortaleza, 2013.

ALMEIDA, J. C. et al. Perfil epidemiológico de casos de surtos de doenças transmitidas por alimentos ocorridos no Paraná, Brasil. Semina: Ciências Biológicas e da Saúde, v. 34, n. 1, p. 97-106, 2013.

ALVES, J. E. et al. Atividade antibacteriana do extrato hidroalcoólico de jatobá-do-cerrado (Hymenaea stigonocarpa Mart. ex Hayne) e barbatimão (Stryphnodendron adstringens (Mart.) Coville). Revista Bionorte, v. 5, n. 1, 2016.

AYYANAR, M.; SUBASH-BABU, P. Syzygium cumini (L.) Skeels: A review of its phytochemical constituents and traditional uses. Asian Pacific journal of tropical biomedicine, v. 2, n. 3, p. 240-246, 2012.

BABILI, F. E. et al. Oregano: chemical analysis and evaluation of its antimalarial, antioxidant, and cytotoxic activities. Journal of food science, v. 76, n. 3, p. C512-C518, 2011.

BARCELOS, I. B. et al. Análise fitoquímica e das atividades citotóxica, antioxidante, e antibacteriana das flores de Tabebuia serratifolia (Vahl) Nicholson. Revista Fitos, Rio de Janeiro, v. 11, n. 1, p. 9-23, set. 2017.

BEZERRA, G. P. et al. Phytochemical study guided by the myorelaxant activity of the crude extract, fractions and constituent from stem bark of Hymenaea courbaril L. Journal of Ethnopharmacology, v. 149, p. 62-69, 2013. 
BITENCOURT, P. E. R. et al. A new biodegradable polymeric nanoparticle formulation containing Syzygium cumini: Phytochemical profile, antioxidant and antifungal activity and in vivo toxicity. Industrial Crops and Products, v. 83, p. 400-407, 2016.

BRASIL. Ministério da Saúde. Secretaria de Atenção à Saúde. Departamento de Atenção Básica. Acolhimento à demanda espontânea. 56 p. Série A. Normas e Manuais técnicos - Cadernos de Atenção Básica n. 28, v I. Brasília, 2011.

BRAND-WILLIAMS, W.; CUVELIER, M. E.; BERSET, C. Use of a free radical method to evaluate antioxidant activity., LWT - Food Science and Technology v. 28, n. 1, p. 25-30, 1995.

BRITO, F. A. et al. Pharmacological study of anti-allergic activity of Syzygium cumini (L.) Skeels. Brazilian Journal of Medical and Biological Research, Ribeirão Preto, v. 40, p. 105-115, 2007.

CAMPOS, M. G. et al. Age-induced diminution of free radical scavenging capacity in bee pollens and the contribution of constituent flavonoids. Journal of agricultural and food chemistry, $\mathrm{v}$. 51, n. 3, p. 742-745, 2003.

CELEDONIO, N. R. Estudo do mecanismo de ação antinociceptivo e antiedematogênico do óleo essencial de Croton argyrophylloides e seus constituintes: alfa-pineno e transcariofileno. 141f. Dissertação (Mestrado em Ciências Fisiológicas) - Universidade Estadual do Ceará, Fortaleza, 2008.

CHANDRASEKARAN, M.; VENKATESALU, V. Antibacterial and antifungal activity of Syzygium jambolanum seeds. Journal of ethnopharmacology, v. 91, n. 1, p. 105-108, 2004.

CLSI M100: Methods for Dilution Antimicrobial Susceptibility Tests for Bacteria That Grow Aerobically; Approved Standard. 30 Ed. 2020.

COE, F. G.; PARIKH, D. M.; JOHNSON, C. A. Alkaloid presence and brine shrimp (Artemia salina) bioassay of medicinal species of eastern Nicaragua. Pharmaceutical Biology, v. 48, n. 4, p. 439445, 2010.

COSTA, M. D. C. M. F. et al. Essential oils from leaves of medicinal plants of Brazilian flora: chemical composition and activity against Candida species. Medicines, v.4, n.2, 27. 2017.

DIAS, C. N. et al. Molluscicidal and leishmanicidal activity of the leaf essential oil of Syzygium cumini (L.) SKEELS from Brazil. Chemistry \& biodiversity, v. 10, n. 6, p. 1133-1141, 2013.

DOLABELA, M. F. Triagem in vitro para atividade antitumoral e anti Trypanossoma cruzi de extratos vegetais, produtos naturais e susbstâncias sintéticas. Master's Degree dissertation, Universidade Federal de Minas Gerais, Belo Horizonte, Brazil, 1997.

DUARTE, M. M. et al. Morphological characterization of fruit, seed and seedling and germination of Hymenaea courbaril L.(Fabaceae)('Jatobá'). Journal of Seed Science, v. 38, n. 3, p. 204-211, 2016. 
FERNANDES, T.T.; SANTOS, A. T.F.; PIMENTA, F.C. Atividade antimicrobiana das plantas Plathymenia reticulata, Hymenaea courbaril e Guazuma ulmifolia. Revista de Patologia Tropical, v. 34, n. 2, p. 113-122, 2005.

FERNANDES, A. W. C. et al. Atividade antimicrobiana in vitro de extratos de plantas do bioma caatinga em isolados de Escherichia coli de suínos. Revista Brasileira de Plantas Medicinais, v. 17, n. 4, p. 1097-1102, 2015.

FERREIRA, S. B. et al. Avaliação da atividade antimicrobiana in vitro do extrato hidroalcóolico de Stryphnodendron adstringens (Mart) Coville sobre isolados ambulatoriais de Staphylococcus aureus. Revista Brasileira de Analises Clinicas, p. 27-31, 2010.

FIGUEIREDO, P. A. Avaliação do potencial antioxidante, citotóxico e fotoprotetor de extratos de Hymenaea courbaril L. e Hymenaea stigonocarpa Mart. ex Hayne. Dissertação (mestrado) - Universidade Estadual Paulista Júlio de Mesquita Filho, Faculdade de Ciências e Letras de Assis, 2014.

GARCIA, C. S.; UEDA, S. M. Y.; MIMICA, L. M.J. Avaliação da atividade antibacteriana in vitro de extratos hidroetanólicos de plantas sobre Staphylococcus aureus MRSA e MSSA. Revista do Instituto Adolfo Lutz, v. 70, n. 4, p. 589-598, 2011.

GARCIA, R. et al. Antimicrobial activity and potential use of monoterpenes as tropical fruits preservatives. Brazilian Journal of Microbiology, v. 39, p.163-168, 2008.

GEORGE, V.; PUSHPANGADAN, P. Biological Activities of Syzygium cumini and Allied Species. In: The Genus Syzygium. CRC Press, p. 133-162, 2017.

GOULART, A. et al. Plantas utilizadas na medicina tradicional para tratamento do diabetes mellitus: uma abordagem in silico. Anais do Salão Internacional de Ensino, Pesquisa e Extensão, v. 8, n. 2, 2016.

GUERRA, A. P. Obtenção, caracterização química e determinação da atividade antimicrobiana do óleo essencial das folhas de Schinus terebenthifolius Raddi (aroeira). Trabalho de Conclusão de Curso. Universidade Tecnológica Federal do Paraná. 2014.

GUNDIDZA, M. et al. Phytoconstituents and biological activities of essential Oil from Rhus lancea L. F. African Journal of Biotechnology, v. 7, n. 16, p. 2787-2789, 2008.

HIRSH, D. C. et al. Microbiologia veterinária. 1.ed. Guanabara Koogan: Rio de Janeiro, 2003.

JARDINI, F. A. Atividade dos compostos fenólicos antioxidantes da romã (Púnica granatum L.) - avaliação in vivo e em culturas de células. Doutorado. Universidade de São Paulo Faculdade de Ciências Farmacêuticas -São Paulo, 2010.

KLEIN E.Y., SUN L, SMITH, D. L., LAXMINARAYAN R. The changing epidemiology of methicillinresistant Staphylococcus aureus in the United States: a national observational study. Am J Epidemiol. 177: 666-74, 2013. 
LIMA, M. F. F. et al. Avaliação toxicológica através do bioensaio com Artemia salina Leach de espécimes vegetais pertencentes à caatinga/Toxicological evaluation by Artemia salina Leach bioassay of caatinga plant specimens. Brazilian Journal of Health Review, v. 2, n. 6, p. 59505963, 2019.

LIMA, I. O. et al. Inhibitory effect of some phytochemicals in the growth of yeasts potentially causing opportunistic infections. Brazilian Journal of Pharmaceutical Sciences, v. 41, n. 2, p. 199-203, 2005.

LOGUERCIO, A. P. et al. Atividade antibacteriana de extrato hidro-alcoólico de folhas de jambolão (Syzygium cumini (L.) Skells). Ciência rural, v. 35, n. 2, p. 371-376, 2005.

LUZIA, D. M. M.; JORGE, N. Composição centesimal, potencial antioxidante e perfil dos ácidos graxos de sementes de jambolão (Syzygium cumini L.). Revista Ciência Agronômica, v. 40, n. 2, p. 219-223, 2009.

MACHADO, R. R.. P. et al. The effect of essential oil of Syzygium cumini on the development of granulomatous infl ammation in mice. Revista Brasileira de Farmacognosia, v. 23, n. 3, p. 488-496, 2013.

MARTINS, C. H. G. et al. Determinação in vitro da Atividade Antibacterianados Extratos Brutos da Casca e Polpa Farinácea de Hymenaea courbaril L. Investigação, v. 10, n. 2-3, 2010.

MARQUES, A. L. A. et al. Surto de salmonelose pelo sorovar Dublin em bezerros no Maranhão. Pesquisa Veterinária Brasileira, v. 33, n. 8, p. 983-988, 2013.

MASSUD. F. J. Medicina Farmacêutica. Artmed Editora, 2016.

MATTOS, K. P. H. et al. Estudo do perfil de resistência de bactérias Gram-negativas em infecções urinárias de origem comunitária: influência da legislação atuante no controle de venda de antimicrobianos. 2014.

MERCÊS, P. F. F. et al. Caracterização fitoquímica e avaliação do potencial acaricida e inseticida do óleo essencial de Hymeneae courbaril L. var. courbaril sobre o ácaro-rajado e o gorgulho do milho. Journal of Environmental Analysis and Progress, v.3, n.4, 417-428, 2018.

MERCÊS, P. F. F et al. Composição química e atividade antibacteriana do óleo essencial dos frutos de Hymenaea courbaril L. var. courbaril. VII SBOE- Simpósio Brasileiro de Óleos Essenciais, 2013.

MEYER, B. N. et al. Brine shrimp: a convenient general bioassay for active plant constituents. Planta medica, v. 45, n. 05, p. 31-34, 1982.

MICHELIN, D. C. et al. Avaliação da atividade antimicrobiana de extratos vegetais. Revista Brasileira de Farmacognosia, v. 15, n. 4, p. 316-320, 2005. 
MISHRA, K., OJHA, H., CHAUDHURY, N.K. Estimation of antiradical properties of antioxidants using DPPH assay: a critical review and results. Food Chem. 130, 1036-1043, 2012.

MORAIS, F.S. et al. Estudo químico e avaliação da atividade antioxidante do óleo essencial e extrato das folhas de Syzygium cumini (L.) Skeels, Dissertação de Mestrado em Ciência e Tecnologia para Recursos Amazônicos - Universidade Federal do Amazonas, Itacoatiara, 2015. $112 f$.

MOHAMED, A. A.; ALI, S. I.; EL-BAZ, F. K. Antioxidant and antibacterial activities of crude extracts and essential oils of Syzygium cumini leaves. Plos one, v. 8, n. 4, 2013.

NIMMO GR. et al. Replacement of healthcare-associated MRSA by community-associated MRSA in Queensland: confirmation by genotyping. J Infect. 67: 439-47, 2013.

NISHANDHINI, SIVALINGAM et al. Chemical Compositions, a-amylase inhibitory and antioxidant activities of the essential oils from unripe fruit pulp and leaves of Syzygium cumini. Int. J. Pharm. Pharm. Sci, v. 7, n. 2, p. 515-519, 2015.

NTZIMANI, A. G.; GIATRAKOU, V. I.; SAVVAIDIS, I. N. Combined natural antimicrobial treatments (EDTA, lysozyme, rosemary and oregano oil) on semi cooked coated chicken meat stored in vacuum packages at 4 C: Microbiological and sensory evaluation. Innovative food science \& emerging technologies, v. 11, n. 1, p. 187-196, 2010.

OLIVEIRA, G. S. et al. Caracterização e comportamento higroscópico do pó da polpa de cajá liofilizada. Revista Brasileira de Engenharia Agrícola e Ambiental, v. 18, n. 10, p. 1059-1064, 2014.

PEREIRA, J. V. et al. Antifungal potential of Sideroxylon obtusifolium and Syzygium cumini and their mode of action against Candida albicans. Pharmaceutical biology, v. 54, n. 10, p. 23122319, 2016.

PEREIRA C.K.B. et al. Composição química, atividade antimicrobiana e toxicidade do óleo essencial de Hymenaea courbaril (jatobá). 30ª REUNIÃO ANUAL DA SOCIEDADE BRASILEIRA DE QUÍMICA. 30. ed. Águas de Lindóia - São Paulo, 2007.

RE, R. et al. Antioxidant activity applying an improved ABTS radical cation decolorization assay. Free radical biology and medicine, v. 26, n. 9-10, p. 1231-1237, 1999.

REED, L. J.; MUENCH, H. A simple method of estimating fifty per cent endpoints. American journal of epidemiology, v. 27, n. 3, p. 493-497, 1938.

RIBEIRO, R. M. et al. Antihypertensive effect of Syzygium cumini in spontaneously hypertensive rats. Evidence-Based Complementary and Alternative Medicine, v. 2014, 2014.

SANTOS, A.E. dos. et al. Extração de compostos bioativos do jambolão (Syzygium Cumini (L.) Skeels) a baixas pressões e livre de solvente orgânico. Dissertação de mestrado - 
Universidade Federal de Santa Catarina, Centro Tecnológico, Programa de Pós-Graduação em Engenharia de Alimentos, Florianópolis, 2017.

SALES, G.D.S. et al. Effects of jambolan (syzygium cumini I. Skeels) in biochemical parameters and in hematopoietic cells'chromosome of rodents. Revista Interdisciplinar de Estudos em Saúde, v. 8, n. 1, p. 183-194, 2019.

SALES, G. W. P. Avaliação da atividade antimicrobiana e do mecanismo de ação do óleo essencial extraído da casca de frutos da Hymenaea courbail L. Dissertação (Mestrado em Ciências Farmacêuticas) - Universidade Federal do Ceará. Faculdade de Farmácia, Odontologia e Enfermagem, Fortaleza, 2014.

SEYFRIED, M. Triagem da atividade antitumoral de extratos vegetais utilizando ensaios de toxicidade in vivo sobre Artemia salina e in vitro sobre células da linhagem HeLa. Dissertação de Monografia de Pós Graduação - Universidade Federal do Paraná, Curitiba, 2010.

SHAFI, P. M. et al. Antibacterial activity of Syzygium cumini and Syzygium travancoricum leaf essential oils. Fitoterapia, v. 73, n. 5, p. 414-416, 2002.

SIMÕES, C. M. O et al. Farmacognosia: do produto natural ao medicamento. Artmed Editora, 2016.

SILVA, M. L. C. et al. Compostos fenólicos, carotenóides e atividade antioxidante em produtos vegetais. Semina: Ciências Agrárias, v. 31, n. 3, p. 669-681, 2010.

SOUSA, M. M. et al. Potencial antioxidante e toxicidade do extrato aquoso de Syzygium cumini (L.) skeels e Spondias mombin L. frente à Artemia salina Leach. XXV Congresso Brasileiro de Ciência e Tecnologia dos alimentos: alimentação a árvore que sustenta a vida. FAURGS, 2016.

SOUSA, M. S. B, VIEIRA, L.M, LIMA, A. Fenólicos totais e capacidade antioxidante in vitro de resíduos de polpas de frutas tropicais. Brazilian Journal of Food Technology, v.14, 202-210, 2011.

SOUZA, L.M.C. Caracterização da droga vegetal ageratum conyzoides I. (asteraceae) e capacidade antioxidante. Anais Seminário de Iniciação Científica, n. 20, 2018.

TOMEI, R. R; SALVADOR, M. J. Metodologias analíticas atuais para avaliação da atividade antioxidante de produtos naturais. Encontro Latino Americano De Iniciação Científica, v. 11, p. 1963-1967, 2007.

TONG, W. Y. et al. Inhibiting enzymatic starch digestion by hydrolyzable tannins isolated from Eugenia jambolana. LWT-Food Science and Technology, v. 59, n. 1, p. 389-395, 2014. 
UCKER, C. D. L et al. Caracterização, atividade antimicrobiana e antioxidante dos óleos essenciais de folhas e sementes de jambolão (Syzygium cumini). Dissertação de Mestrado. Universidade Federal de Pelotas, 2016.

VARGAS, E. C. A. et al. Uso de Plantas com Fins Terapêuticos por Usuários de uma Unidade PréHospitalar Pública de Campos dos Goytacazes, Rio de Janeiro, Brasil. Revista de Pesquisa: Cuidado é Fundamental, p. 1129-1134, 2019.

VEGGI, P.C. et al. Obtaining phenolic compounds from jatoba (Hymenaea courbaril L.) bark by supercritical fluid extraction. Journal of Supercritical Fluids, v.89, 68-77, 2014.

VENCATO, S. B. et al. Avaliação do perfil fitoquímico e potencial antioxidante do extrato aquoso de hymenaea courbaril. Revista de Iniciação Científica da ULBRA, n. 14, 2016.

VERPOORTE, R.; DIHAL, P. P. Medicinal plants of Surinam IV. Antimicrobial activity of some medicinal plants. Journal of ethnopharmacology, v. 21, n. 3, p. 315-318, 1987.

WATERHOUSE, A. L. Wine phenolics. Annals of the New York Academy of Sciences, v. 957, n. 1, p. 21-36, 2002.

XAVIER, M. A. Estudos com extrato de Syzygium cumini (L.) Skeel: Perfil fitoquímico e atividade antimicrobiana sobre Candida albicans. 2015.

YANG JIANG. et al. Chemical composition and antimicrobial activity of the essential oil of Rosemary. Environmental Toxicology and Pharmacology, v. 32, n. 1, p. 63- 68, 2011.

\section{Authorship contributions}

\section{1 - Gustavo Oliveira Everton}

Mestrado em Biotecnologia aplicada à saúde

https://orcid.org/0000-0002-0457-914X e gustavooliveiraeverton@gmail.com

Contribuição: Conceituação, Análise Formal, Investigação, Metodologia, Recursos, Programas, Supervisão, Validação, Visualização, Escrita - rascunho original, Escrita revisão e edição

\section{2 - Ana Patrícia Matos Pereira}

Especialista em Microbiologia Clínica

https://orcid.org/0000-0003-1782-5896 e ap.matos11@hotmail.com

Contribuição: Metodologia, Escrita - rascunho original, Escrita - revisão e edição.

\section{3 - Paulo Victor Serra Rosa}

Graduação em Biomedicina

https://orcid.org/0000-0003-1782-5896 e paullovictorserra@gmail.com

Contribuição: Metodologia, Escrita - rascunho original, Escrita - revisão e edição 


\section{4 - Nilton Silva Costa Mafra}

Graduando em Engenharia Química

https://orcid.org/0000-0002-5353-0596 e nilton.mafra@hotmail.com

Contribuição: Metodologia, Escrita - rascunho original, Escrita - revisão e edição

\section{5 - Paulo Sérgio Santos Júnior}

Graduando em Engenharia Química

https://orcid.org/0000-0002-9628-5594 e psjr08@gmail.com

Contribuição: Metodologia, Escrita - rascunho original, Escrita - revisão e edição

\section{6 - Franscristhiany Silva Souza}

Mestrado em Química

https://orcid.org/0000-0001-8674-1552 e frans_msc@hotmail.com

Contribuição: Metodologia, Investigação, Metodologia, Recursos

\section{7- Caritas de Jesus Silva Mendonça}

Doutorado em Tecnologia de Alimentos

https://orcid.org/0000-0002-9479-810X e caritasflordelotus@gmail.com

Contribuição: Metodologia, Investigação, Metodologia, Recursos

\section{8 - Fernando Carvalho Silva}

Doutor em Química

https://orcid.org/0000-0001-9229-8251 e fcs.ufma@gmail.com

Contribuição: Metodologia, Investigação, Metodologia, Recursos

\section{9 - Paulo Roberto Barros Gomes}

Mestrado em Química

https://orcid.org/0000-0002-4221-6577 e prbgomes@yahoo.com.br

Contribuição: Metodologia, Investigação, Metodologia, Recursos

\section{0 - Victor Elias Mouchrek Filho}

Doutorado em Química

https://orcid.org/0000-0003-2855-7292 e victor.mouchrek@ufma.br Contribuição: Metodologia, Investigação, Metodologia, Recursos 